\title{
Distribution and population trends of waterbird species wintering in Basque estuaries (North of Spain): a 22-year study
}

Peru Barainka ${ }^{1}$, Juan Arizaga'

\begin{abstract}
The loss and/or degradation of coastal marshes has had a dramatic impact on the conservation of several waterbird species worldwide. The Basque region is a hot spot for migrants entering Iberia via the East Atlantic flyway. Our aim was to describe the distribution of waterbirds and assess population trends of waterbirds that overwinter along this coast. To achieve these goals we used data from the annual winter survey for the period 1992-2013. The yellow-legged gull Larus michahellis Naumann, 1840 and the black-headed gull Chroicocephalus ridibundus (L., 1766) comprised ca. $80 \%$ of bird abundance. The waterbird assemblage wintering on these estuary areas consists, accordingly, of a relatively homogeneous community, dominated by gulls. This assemblage, moreover, is also small in terms of abundance, and from a peninsular standpoint its importance is low, although, locally, it is important. The assemblage was subdivided into two clusters: one was dominated by the yellow-legged gull, and the other one by the black-headed gull. Finally, most of the species had uncertain or stable population trends, with only five species showing positive population trends, and two having negative trends. Causes underlying such trends remain unidentified.
\end{abstract}

Keywords: Basque Country, winter counts; bird conservation; gulls; wetlands.

\section{Resumen}

La desaparición o degradación de las marismas costeras ha tenido un efecto claramente negativo en la conservación de varias especies de aves acuáticas. El País Vasco es una región que constituye un punto clave de paso para las aves migratorias que recorren la ruta del Atlántico oriental. El objetivo de este artículo es describir la distribución y tendencia de las poblaciones de aves acuáticas que invernan en las marismas costeras del País Vasco. Para ello se utilizaron datos del censo invernal de aves acuáticas, para el periodo 1992-2013. Las gaviotas patiamarilla Larus michahellis Naumann, 1840 y reidora Chroicocephalus ridibundus (L., 1766) acumulan

\footnotetext{
1 Aranzadi Society of Sciences. Department of Ornithology

Zorroagagaina 11 • E-20014 Donostia-S. Sebastián, Spain

* Corresponding author: jarizaga@aranzadi.eus
} 
el $80 \%$ de la abundancia de acuáticas. El ensamblado de las acuáticas que invernan en los estuarios vascos es, en consecuencia, homogéneo. Este ensamblado, además, es pequeño en términos de abundancia, por lo que se deriva que los estuarios vascos tienen un peso marginal para la invernada de acuáticas a escala peninsular, si bien localmente son muy relevantes. Los estuarios se agrupan en dos "clusters", dominados, respectivamente, por las dos especies de gaviotas mencionadas anteriormente. Finalmente, observamos que la mayoría de las especies mostraron tendencias poblacionales inciertas o estables, habiendo sólo 5 especies con tendencia positiva y dos con tendencia negativa. Las causas que explican este patrón son aún desconocidas.

Palabras clave: País Vasco, censos de invernantes, conservación de aves, gaviotas, humedales.

\section{Laburpena}

Kostako paduren desagertzeak edo degradazioak uretako hegazti urtarren espezie batzuen biziraupenean ondorio kaltegarri nabarmenak izan ditu. Euskal Herria funtsezko igarobidea da Atlantiar ekialdeko bidea egiten duten hegazti migratzaileentzat. Artikulu honen helburua da Euskal Herriko kostaldeko paduretan negua ematen duten uretako hegaztien banaketa eta populazioen joera deskribatzea. Lan horretarako, 1992-2013 bitartean jasotako ur-hegaztien neguko errolda datuak erabili ziren. Antxeta hanka hori Larus michahellis Naumann, 1840 eta antxeta moko gorriak Chroicocephalus ridibundus (L., 1766) ur-hegaztien kopuruaren \%80 osatzen dute. Beraz, Euskal Herriko paduretan negua igarotzen duten ur-hegaztien multzoa homogenoa da. Ugaritasunari dagokionez, multzoa txikia dela ere gaineratu daiteke eta, ondorioz, esan daiteke euskal padurak penintsula mailan ur-hegaztien hibernaziorako marginalak direla, nahiz eta maila lokalean garrantzitsuak diren. Padurak bi taldetan multzokaturik daude, lehen aipatu diren bi antxeta espezieak nagusi direlarik. Azkenik, argi ikusi zen espezie gehienek ez zutela populatze joera ezagun edo egonkorrik, soilik bostek erakutsi zutelarik joera positiboa eta bik, berriz, joera negatiboa. Joera horiek azalduko lituzketen arrazoiak oraindik ezezagunak dira.

Gako hitzak: Euskal Herria, hibernanteen errolda, hegaztien biziraupena, antxeta, padurak.

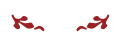

\section{Introduction}

Wetlands are habitats of critical relevance for bird conservation because many species depend on them either directly or indirectly, permanently or temporally (Weller, 1999; Boere et al., 2006). Estuaries probably are among the most globally endangered wetlands (Beazley, 1993; Keddy, 2010). Their location in strategic areas of human interest has promoted severe habitat changes, mostly to facilitate commercial, industrial, agricultural, urban and livestock use (Beazley, 1993). The loss and/or degradation of estuary marshes has had a dramatic impact on the conservation of several waterbird species (species 
defined as those which ecologically depend on wetlands) worldwide (Rose \& Scott, 1997; Madroño et al., 2004). Migratory waterbirds are particularly vulnerable to this phenomenon, since these birds depend on a network of wetland areas that has become increasingly disconnected (Smit \& Piersma, 1989; Boere et al., 2006). Understanding how these birds use particular wetland sites and where and when they are found is basic from the conservation and management standpoints (Rendón et al., 2008; Zwarts et al., 2009; Almaraz et al., 2012).

Each winter, southern European wetlands host hundreds of thousands of waterbirds breeding in northern Europe (Amat \& Ferrer, 1988; Obeso, 1988; Tellería, 1988; SEO/BirdLife, 2012). The number of waterbirds spending the winter in Iberia accounts for ca. $>40 \%$ of the waterbird individuals wintering through the western Mediterranean wetlands (Rose \& Scott, 1997). In the Atlantic region of northern Iberia, the most relevant wetlands are situated along the coast, and most are in estuaries. The size of such estuaries ranges from only a few hectares up to $>3000$ ha at the largest one, the Santander bay. Situated in northern Iberia, the Basque coast is known to be a hot spot for bird migrants entering Iberia via the East Atlantic flyway (Galarza \& Tellería, 2003; Tellería et al., 2009), including waterbirds (Galarza \& Domínguez, 1989; Anónimo, 1996; Garaita, 2012).

The characteristics of the assemblage of waterbird populations wintering along this coast, the role of the coast for the conservation of this group of birds and their population trends are questions that have not been dealt with specifically in any of the existing scientific literature, which deals with much larger geographic areas (González \& Pérez-Aranda, 2011). The aims of this study were to (1) describe the assemblage of waterbirds that overwinter in the Basque estuaries and determine clusters of estuaries in relation to the species and bird numbers that they host, and (2) estimate their population trend. To achieve these goals we used data from the annual winter survey for the period 1992-2013.

\section{Material and methods}

\section{Sampling area and data collection}

This study was carried out at the 15 estuaries existing along the Basque coast, which occupy an area of about 5000 ha (the southeast Bay of Biscay, North of Spain; Fig. 1; Table 1). Estuary size ranged from $<5$ to 1660 ha (Table 1).

In comparison to other coastal sites in southern Iberia, or even in the rest of the Bay of Biscay in northern Iberia, our estuaries are highly deteriorated. Most of them have been transformed to build mainly urban or industrial surfaces. The best preserved estuaries (with $>5$ ha of natural habitat, i.e. non-urbanized littoral including intertidal flats, sandy areas and marsh-associated vegetation, such as reed beds or intertidal prairies of halophytic vegetation) are (from east to west): Txingudi, Zarautz, Zumaia, Urdaibai and Plentzia (Table 1). The remainder have no, or only very little ( $<5$ ha) natural habitat surface. 


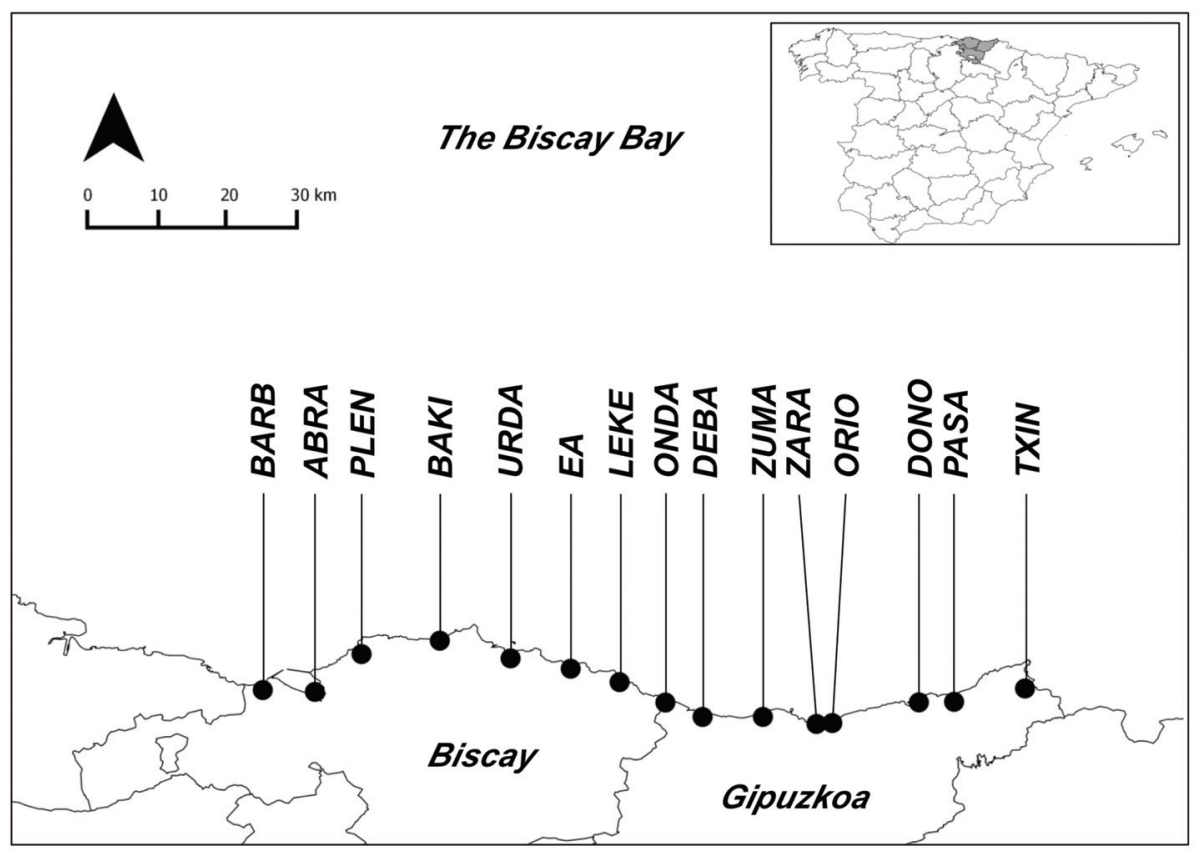

Fig. 1.- Estuaries where the study was carried out. Abbreviations as in Table 1. The Basque region is shadowed within the small map of Spain; the provinces of Biscay and Gipuzkoa are indicated.

Fig. 1.- Estuarios estudiados en este artículo. Abreviaciones, Tabla 1. El País Vasco es el área oscura en el mapa de España; se han indicado las provincias de Bizkaia y Gipuzkoa.

Eight estuaries are partially or fully included within the Nature 2000 European network (Table 1).

Data on bird counts were obtained from a number of institutions and volunteers who participated in the annual winter census, which is carried out in mid-January in all relevant wetlands worldwide (for details see wpe.wetlands.org). Census data for the Basque wetlands were compiled by the Basque Government and can be downloaded from the Internet (www.ingurumena.ejgv.euskadi.net).

Census data consisted of waterbird counts conducted during a single survey day at each site. We included as waterbirds: divers, grebes, cormorants, herons, storks and ibises, ducks, geese and swans, western marsh harrier Circus aeruginosus (L., 1758), gallinules, rails and coots, shorebirds, gulls and terns, auks, and the Eurasian kingfisher Alcedo atthis (L., 1758) (Appendix I, reference at the end of the article). Censuses at each site were conducted using a fixed, standard survey protocol, which consisted of counting waterbirds at high tide, always from the same points, covering the same survey area and, where possible, using the same observer from year to year. Thus, data from each site were reasonably comparable from year to year. 


\begin{tabular}{|lcccccc|}
\hline Name & Code & $\begin{array}{c}\text { Area } \\
\text { (ha) }\end{array}$ & $\begin{array}{c}\text { Natural } \\
\text { habitat }\end{array}$ & Ramsar & Natura & Non-sampling years \\
\hline Barbadun & BARB & 253 & No & No & Yes & 1993, 1995, 1998, 2000-2001, 2007 \\
Abra & ABRA & 1660 & No & No & No & 2001 \\
Plentzia & PLEN & 182 & Yes & No & No & 2001-2002 \\
Bakio & BAKI & $<5$ & No & No & No & $1992-1996,2000-2003,2008,2010-2013$ \\
Urdaibai & URDA & 1100 & Yes & Yes & Yes & 2001 \\
Ea & EA & $<5$ & No & No & No & $1992,2001,2003,2009-2013$ \\
Lekeitio & LEKE & 30 & No & No & Partially & 2001 \\
Ondarroa & ONDA & 62 & No & No & Partially & 19001 \\
Deba & DEBA & 50 & No & No & No & $1992,1998-1999,2007$ \\
Zumaia & ZUMA & 209 & Yes & No & Yes & 1995,1998 \\
Zarautz & ZARA & 55 & Yes & No & Yes & $1994-1995$ \\
Orio & ORIO & 258 & No & No & Partially & $1994-1995,2002-2003,2007$ \\
Donostia & DONO & 415 & No & No & No & $1995,1998-1999$ \\
Pasaia & PASA & 270 & No & No & No & $1995,1998,2003,2005$ \\
Txingudi & TXIN & 480 & Yes & Yes & Yes & None \\
\hline
\end{tabular}

Table 1.- Characteristics of the 15 estuary areas located on the Basque coast. Estuaries shown from west to east.

Tabla 1.- Características de los 15 estuarios, ordenados de oeste a este, de la costa vasca.

The period analysed in our study was from 1992 to 2013. However, there were years in which some sites (estuaries) were not surveyed (Table 1). Furthermore, at Urdaibai, we had ten non-systematically counted species: red-breasted merganser Mergus serrator, water rail Rallus aquaticus L., 1758, common moorhen Gallinula chloropus (L., 1758), Eurasian coot Fulica atra L., 1758, common snipe Gallinago gallinago (L., 1758), common sandpiper Actitis hypoleucos (L., 1758), yellow-legged gull Larus michahellis Naumann, 1840, lesser blackbacked gull Larus fuscus L., 1758, black-headed gull Chroicocephalus ridibundus (L., 1766), common kingfisher.

\section{Data analyses}

For all analyses, the ten non-systematically counted species at Urdaibai were removed from the data set. Moreover, though included within the original data set, the northern 
gannet Morus bassanus (L., 1758) was removed from our data because the majority of these birds were flying close to the coast and did not stop over or settle at any of our estuaries.

We first identified which species were dominant at each site. With that goal, for each site and species the mean annual number of counts was calculated for those years when the site was surveyed (Table 1). Thereafter, these averages were added to obtain the global assemblage and to determine which species were dominant overall.

Second, we studied the between-sites similarity based on a quantitative matrix of bird abundances. We used for that a Hierarchical Analysis of Clusters using the Past 2.17 software (Hammer et al., 2001). The clusters were created using the UPGMA method (Krebs \& Davis, 1993), from a similarity matrix based on the quantitative Morisita's index (Magurran, 2004). This matrix was built using for each site and species the mean annual number of counts, which was calculated for those years when the site was surveyed. To perform this analysis, Urdaibai was also excluded because not all species were surveyed th this site.

Finally, we calculated the population trends with the software TRIM (Pannekoek \& Van Strien, 2005). TRIM is conceived to handle with survey gaps (missing surveys) within the data sets, so in this case we used all the data available for each site. We used for the analyses the most abundant waterbirds (33 species overall; these with annual mean abundances $>10$ specimens); sites where a certain species was never seen were removed from the analysis for that species. Moreover, some species were first observed after 1992. In these cases, TRIM analyses were run only considering the time-series starting in the year when the species was first found.

TRIM allows us to test for the fit of either log-linear trend models or time-effect models to the data. Log-linear trend models assume a constant increase $(\beta)$ in the log-expected counts from one year (or time unit) to the next and time-effect models provide yearly parameter estimates. Although linear trend models can provide unrealistic figures over longterm periods, they work well with short-term series and can be used even if we lack positive counts for all time points (years), a common circumstance (González \& PérezAranda, 2011).

Log-linear trend models can be written as: $\ln \left(\operatorname{counts}_{i j}\right)=a_{j}+\beta(j-1)$, i.e. the number of counts at a site $i$ in year (time) $j$ is an additive function of the site-effect and the annual population growth rate, $\beta$. In this equation, the first time point (year) within the series is 1 by definition. Hence, the multiplicative function is: $\left(\right.$ counts $\left._{i j}\right)=\exp \left(\alpha_{j}\right) \times \exp (\beta)^{(j-1)}$. The parameters obtained by TRIM for each model were: model overall imputed slope ( $\pm \mathrm{SE})$, annual population growth rate (expressed as a percentage) and its significance (uncertain, moderate to strong increase, moderate to strong decrease). We showed the multiplicative parameter estimates, which show change in terms of mean percentage change per year. If $\beta$ is 1 , then there is no trend; and if for instance $\beta$ is 1.08 , the population has a growth rate of $8 \% /$ year. 


\section{Results}

\section{Bird assemblage and geographic distribution of waterbirds}

From 1992 to 2013, the sum of the per-site mean annual number of waterbirds at all estuaries was 18454 individuals. Note, however, that this value is below the real one because ten species were not surveyed at Urdaibai. We registered 97 species overall (Appendix I).

Abra was the most important site in terms of abundance, with an annual mean of 6082 \pm 3398 individuals. At the opposite end was Ea, with $36 \pm 40$ individuals. The majority of the estuaries had a mean waterbird annual abundance $<500$ individuals (Fig. 2).

The most abundant species was the yellow-legged gull, and three out of the ten most abundant birds were gulls (Fig. 3). The yellow-legged gull was also the dominant bird at eight sites, while the black-headed gull was the most abundant bird at five estuaries (Fig. 4). For the remaining two sites (Deba and Urdaibai) the most abundant waterbirds were the little egret Egretta garzetta L., 1758 and the dunlin Calidris alpina (L., 1758).

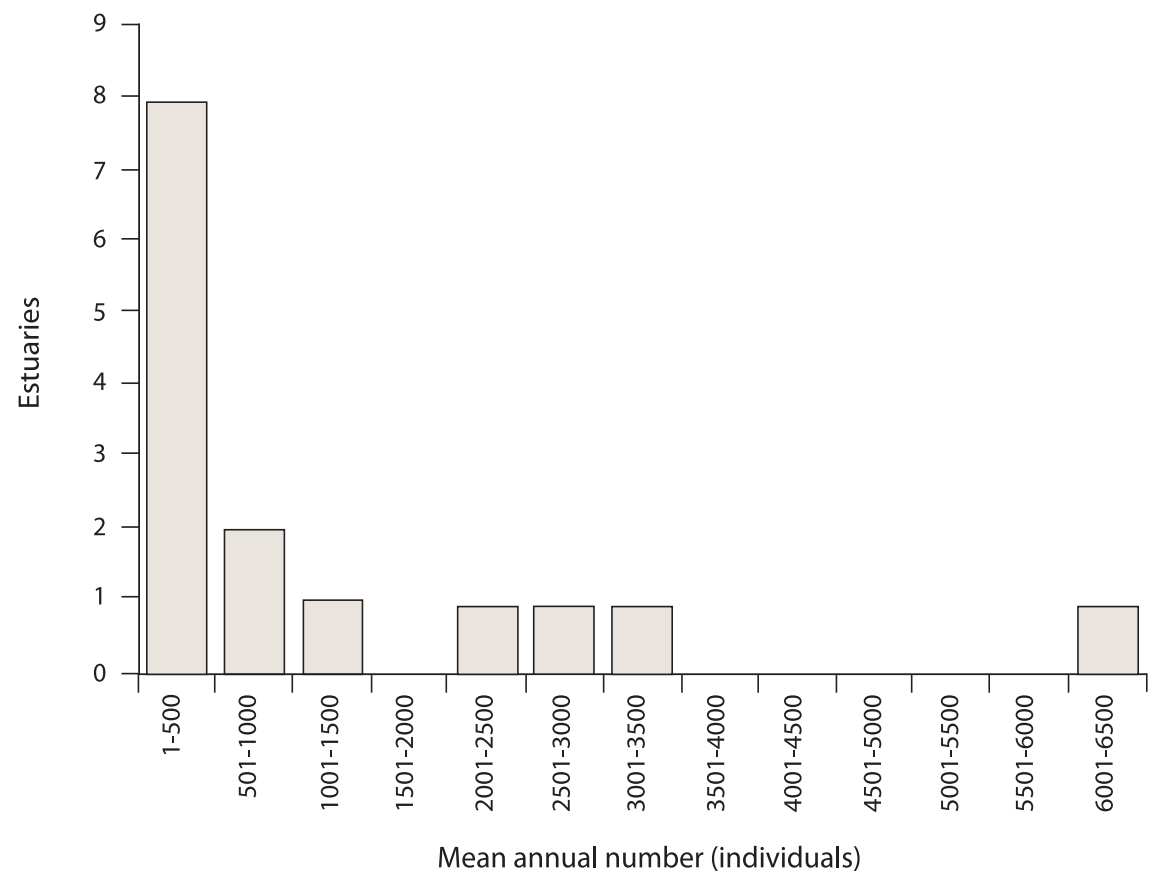

Fig. 2.- Mean annual number of waterbirds occurring at the Basque estuaries during the winter.

Fig. 2.- Número medio anual de aves acuáticas presentes en los estuarios vascos en invierno. 


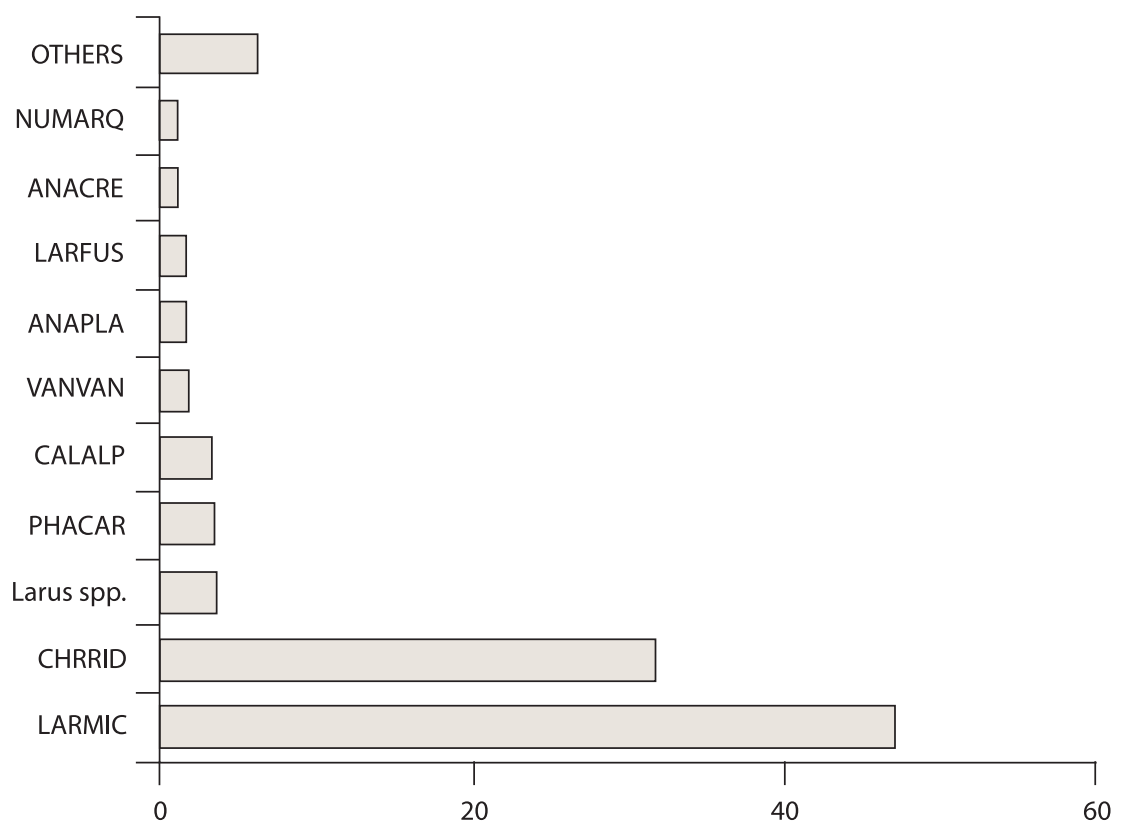

Abundance (\%)

Fig. 3.- Relative winter abundance of the most abundant waterbirds in Basque estuaries. Species code as in Appendix I. Larus spp. lumps gulls for which the species was not possible to be determined. This mostly affected to sub-adult mixed flocks of yellow-legged and lesser-black-backed gulls.

Fig. 3.- Abundancia relativa de las especies más abundantes en los estuarios vascos durante el invierno. Código de especies como en el Apéndice I. Larus spp. aglutina a varias especies de gaviotas en las que no se identificó la especie. Esto afectó principalmente a bandos mixtos de subadultos de gaviota sombría y patiamarilla.

However, the data from Urdaibai are, once more, biased because large gulls were not surveyed at this site.

The Hierarchical Analysis of Clusters revealed two clusters (Fig. 5). One of the clusters was observed to be made up of estuaries dominated by gulls (mostly the yellow-legged gull), while the other included relatively high abundances of other species apart from gulls, such as the dunlin and the mallard Anas platyrhynchos L., 1758 (Fig. 6). In the last cluster, the dominant species was the black-headed gull.

From 33 species considered overall, 22 (66.6\%) showed uncertain trends, 5 (15.2\%) showed positive population trends, 2 (6.1\%) showed moderate negative trends (all of them were waders), and 5 had stable populations (Table 2). 

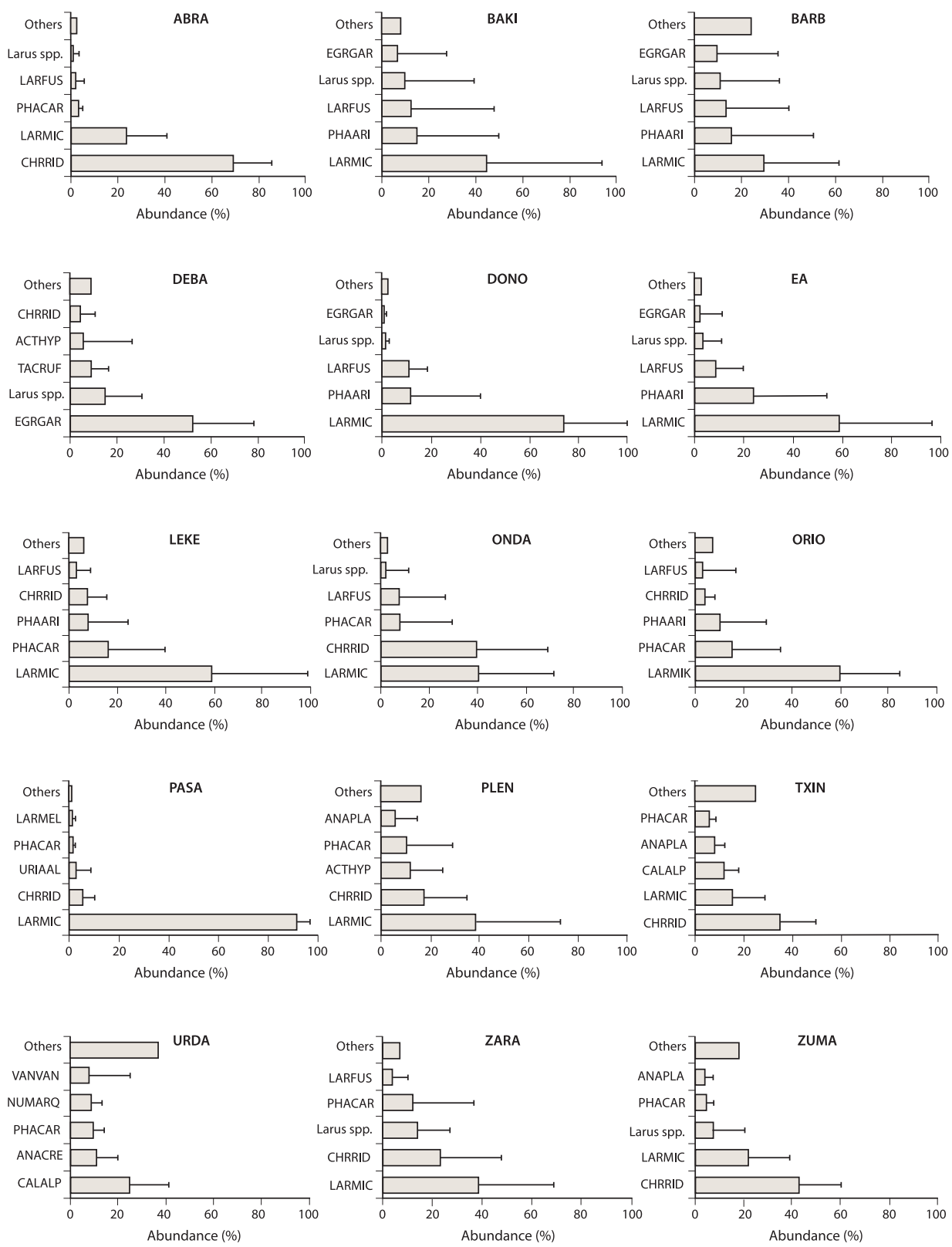

Fig. 4.- Relative abundance (mean \pm SD) of the five most abundant waterbirds at the 15 Basque estuaries. Note that not all species were counted at Urdaibai (Appendix II). Species code as in Appendix I

Fig. 4. Abundancia relativa (media \pm SD) de las especies más abundantes en los 15 estuarios vascos. Nótese que en el caso de Urdaibai no se censaron todas las especies (Apéndice II). Código de especies como en el Apéndice I 


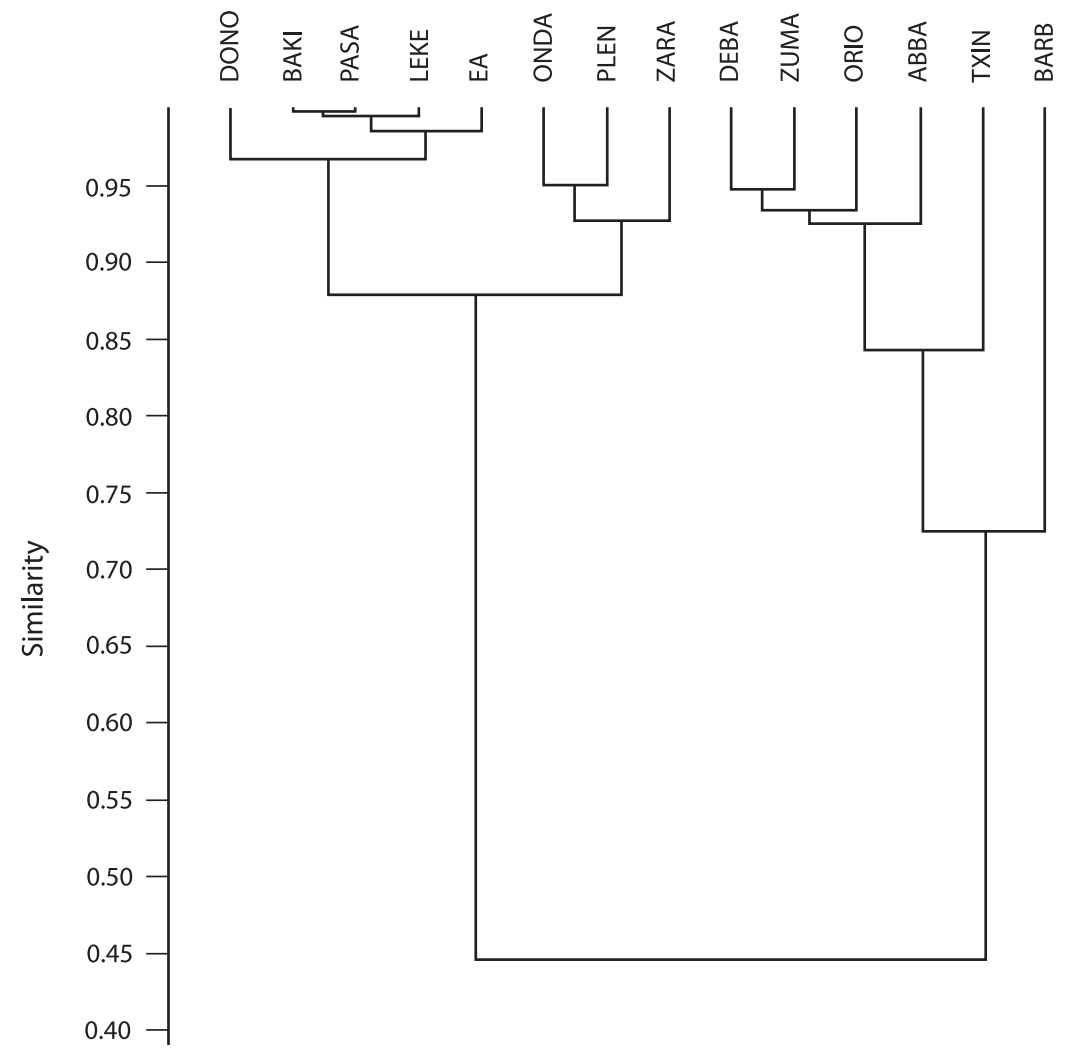

Fig. 5.- Diagram derived from a Hierarchical Analysis of Clusters used to examine the similarity of 14 Basque estuaries. Urdaibai has not been considered here because not all species were counted at this site.

Fig. 5. Diagrama derivado de un análisis de clusters empleado para examinar la similaridad de 14 estuarios de la costa vasca. Urdaibai no se ha incluido porque en este estuario no se censaron todas las especies.

Table 2.- Results from the log-linear (TRIM) models used to estimate the population growth rate (overall slope imputed) of several waterbird species wintering on the Basque estuaries from 1992 to 2013. We show the parameter estimates and their SE error, also expressed as a percentage of annual growth rate, and the significance of this rate $(\mathrm{U}=$ uncertain; $\mathrm{S}=$ stable; $\mathrm{MI}$, moderate increase, $\mathrm{SI}=$ strong increase; $\mathrm{MD}=$ moderate decrease, $\mathrm{SD}=$ strong decrease). Models have been run for those species which had an annual mean abundance $>10$ individuals.

Tabla 2.- Resultados de los modelos log-lineales (TRIM) utilizados para determinar la tasa de crecimiento poblacional de varias especies de aves acuáticas invernantes en los estuarios vascos durante el periodo 1992-2013. Se muestran las estimaciones de los parámetros y su SE, así como la tasa de crecimiento anual poblacional (en porcentaje) y su significación ( $U$ = incierto; $\mathrm{S}=$ estable; $\mathrm{MI}=$ incremento moderado; $\mathrm{SI}=$ incremento fuerte; $\mathrm{MD}=$ descenso moderado; $\mathrm{SD}=$ descenso fuerte). Modelos llevados a cabo sólo para las especies con una abundancia media anual >10 individuos. 


\begin{tabular}{|c|c|c|c|}
\hline Species & $\exp (ß) \pm S E$ & Trend (\%) & Statistical trend \\
\hline \multicolumn{4}{|l|}{ GREBES } \\
\hline Little grebe & $1.100 \pm 0.038$ & $+10.0 \%$ & $\mathrm{Ml}$ \\
\hline Great-crested grebe & $1.029 \pm 0.031$ & $+2.9 \%$ & $U$ \\
\hline Black-necked grebe & $1.097 \pm 0.064$ & $+9.7 \%$ & U \\
\hline \multicolumn{4}{|l|}{ CORMORANTS } \\
\hline Great cormorant & $1.003 \pm 0.008$ & $+0.3 \%$ & S \\
\hline European shag & $1.056 \pm 0.016$ & $+5.6 \%$ & $\mathrm{Ml}$ \\
\hline \multicolumn{4}{|l|}{ HERONS } \\
\hline Grey heron & $0.989 \pm 0.008$ & $-1.1 \%$ & S \\
\hline Little egret & $1.009 \pm 0.008$ & $+0.9 \%$ & s \\
\hline Cattle egret $^{1}$ & $1.301 \pm 0.693$ & $+30.1 \%$ & $u$ \\
\hline \multicolumn{4}{|l|}{ DUCKS and GEESE } \\
\hline Greylag goose ${ }^{2}$ & $1.056 \pm 0.067$ & $+5.6 \%$ & U \\
\hline Eurasian wigeon & $0.998 \pm 0.169$ & $0 \%$ & U \\
\hline Gadwall ${ }^{2}$ & $1.353 \pm 4.502$ & $+35.3 \%$ & U \\
\hline Eurasian teal & $1.204 \pm 0.055$ & $+20.4 \%$ & SI \\
\hline Mallard & $1.171 \pm 0.329$ & $+17.1 \%$ & U \\
\hline Northern shoveler & $1.175 \pm 0.061$ & $+17.5 \%$ & $\mathrm{SI}$ \\
\hline \multicolumn{4}{|l|}{ COOTS } \\
\hline Common moorhen & $1.095 \pm 0.108$ & $+9.5 \%$ & U \\
\hline Eurasian coot & $1.0543 \pm 0.036$ & $+5.4 \%$ & U \\
\hline \multicolumn{4}{|l|}{ WADERS } \\
\hline Northern lapwing & $1.025 \pm 0.953$ & $+2.5 \%$ & U \\
\hline Eurasian oystercatcher & $0.990 \pm 0.139$ & $-1.0 \%$ & U \\
\hline Grey plover & $0.936 \pm 0.024$ & $-6.4 \%$ & $M D$ \\
\hline Common ringed plover & $0.953 \pm 0.031$ & $-4.7 \%$ & U \\
\hline Eurasian curlew & $0.975 \pm 0.051$ & $-2.5 \%$ & u \\
\hline Redshank & $1.036 \pm 0.020$ & $+3.6 \%$ & U \\
\hline Common greenshank & $1.074 \pm 0.521$ & $+7.4 \%$ & U \\
\hline Ruddy turnstone & $1.161 \pm 0.028$ & $+16.1 \%$ & SI \\
\hline Common sandpiper & $1.082 \pm 0.056$ & $+8.2 \%$ & U \\
\hline Purple sandpiper & $0.973 \pm 0.017$ & $-2.7 \%$ & u \\
\hline Dunlin & $0.951 \pm 0.011$ & $-4.9 \%$ & $\mathrm{MD}$ \\
\hline \multicolumn{4}{|l|}{ GULLS } \\
\hline Yellow-legged gull & $1.009 \pm 0.016$ & $+0.9 \%$ & S \\
\hline Lesser black-backed gull & $1.035 \pm 0.056$ & $+3.5 \%$ & U \\
\hline Black-headed gull & $1.008 \pm 0.007$ & $+0.8 \%$ & S \\
\hline Mediterranean gull & $1.186 \pm 0.456$ & $+18.6 \%$ & U \\
\hline \multicolumn{4}{|l|}{ AUKS } \\
\hline Common guillemot & $1.015 \pm 0.269$ & $+1.5 \%$ & U \\
\hline Razorbill & $1.044 \pm 0.151$ & $+4.4 \%$ & U \\
\hline
\end{tabular}

${ }^{1}$ Time series starting in 2000. ${ }^{2}$ Time series starting in 1993. 

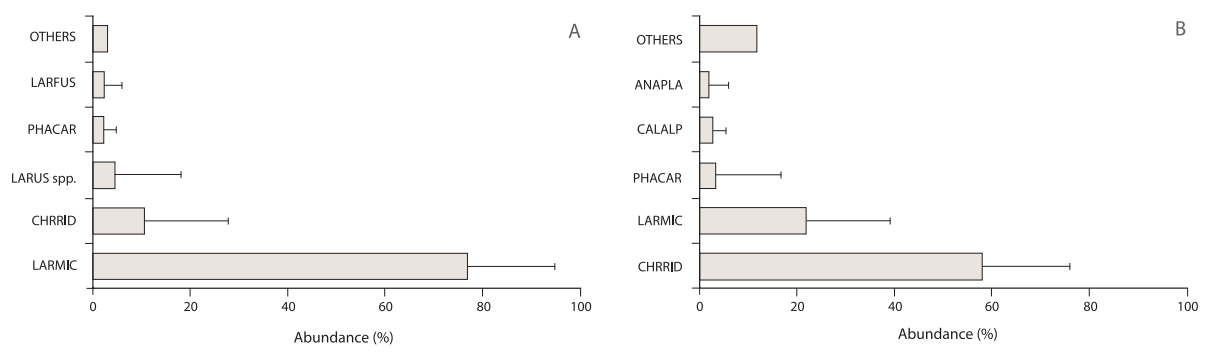

Fig. 6.- Relative abundance (mean $\pm S D$ ) of the five most abundant waterbirds in the two clusters obtained in Fig. 4 (A: DONO, BAKI, PASA, LEKE, EA, ONDA, PLEN, ZARA; B: DEBA, ZUMA, ORIO, ABRA, TXIN, BARB). Species code as in Appendix I.

Fig. 6. Abundancia relativa (media $\pm S D$ ) de las especies más abundantes en cada uno de los dos clusters de la Fig. 4. (A: DONO, BAKI, PASA, LEKE, EA, ONDA, PLEN, ZARA; B: DEBA, ZUMA, ORIO, ABRA, TXIN, BARB). Código de especies como en el Apéndice I.

\section{Discussion}

\section{Sampling area and data collection}

The mean annual number of waterbirds wintering at the Basque estuaries was estimated to be ca. 18000 for the period 1992-2013. This is 1\% of the waterbirds that overwinter in Spain (ca. 1700000), but 60\% of the waterbirds that overwinter in all the Basque wetlands (more than 30000 individuals) (González \& Pérez-Aranda, 2011). The population size of any of the species was $<<1 \%$ of the East Atlantic flyway population (Wetlands International, 2012). The Basque estuaries therefore play a relatively marginal role as a target region for waterbird species wintering in Spain. From a regional (Basque) perspective, however, they still have great value if we take into account that some species (e.g. divers, auks, several gull species) are observed only or mostly at these coastal sites. These estuaries therefore make a relevant contribution to the enrichment of the waterbird assemblage on a local (regional) scale (e.g., Ihobe, 2012). The contribution of the Basque estuaries to the waterbird assemblage wintering along the coast of northern Iberia is also moderate. Thus, all the Basque estuaries hosted almost the same or even less (Navedo et al., 2007) waterbirds than the nearby Santoña Marshes, situated just $30 \mathrm{~km}$ west of the westernmost Basque estuary (Barbadún). The Basque estuaries comprised ca. 6.6\% of the waterbird assemblage wintering in Northern-Atlantic Spain (i.e. Asturias, Cantabria, Basque Country and Galicia) (González \& Pérez-Aranda, 2011).

The relatively small importance of the Basque estuaries for the waterbird assemblage from a northern Iberian perspective is likely to be associated with a number of causes, which would need specific research to be determined. Here, we can advance two main causes: (1) their relatively small size (i.e., a naturally restricted carrying capacity), and (2) the degra- 
dation of the natural habitat (i.e., an artificially restricted carrying capacity). It has been calculated that only $10 \%$ of the original estuary-related habitats exist today on these estuary areas. This has been the main threat for the conservation of waterbirds within the region, which would probably have the capacity to host more waterbirds if the natural habitat were to be restored. For instance, the creation of a lagoon at Urdaibai caused a rapid increase in the numbers of some waterbirds (e.g., ducks and coots) in this area (Arizaga et al., 2014).

It is also interesting to note the need for having complete species surveys at Urdaibai. Although it is one of the most important Basque estuaries, both in terms of abundance and specific richness, it is sad to note that some taxa of great value from the assemblage and ecological functioning perspective, such as some gulls, are not systematically surveyed at this site.

The yellow-legged gull was the most abundant bird. It is a resident bird in the area, with a population of ca. 4000 breeding pairs to which we should add local sub-adults and wintering conspecifics coming from the Mediterranean, the Atlantic, and inland centralwestern Europe (Arizaga et al., 2009; Galarza et al., 2012). The black-headed gull was the second most frequent bird, reaching a higher abundance than even the yellow-legged gull in some estuaries, including important estuaries like Txingudi. Overall, the yellowlegged and the black-headed gull can reach similar abundances along the coast of the Basque Country in certain winters (Obeso, 1988). The distribution and abundance of these two species may be associated with factors like the geographic distribution of the yellowlegged gull colonies (Arizaga et al., 2009) or occurrence of main foraging places (Arizaga et al., 2013). Interestingly, we observed two clusters, dominated, respectively, by the yellow-legged and the black-headed gulls, which were found to be the two most abundant species overall. Causes underlying this phenomenon also remain unclear to us.

Estuary areas that still contain natural habitat, more particularly mudflats (Granadeiro et al., 2004; Santos et al., 2005), hosted higher numbers of dunlins, which was the third most abundant waterbird. The dunlin is, in fact, one of the most abundant shorebirds along the coast of northern Iberia (Smit \& Piersma, 1989; Domínguez, 1997; Avilés \& Parejo, 1999; Navedo et al., 2007). With ca. 500 individuals, however, the contribution of the Basque estuaries to the population spending the winter in northern Iberia is weak (González \& Pérez-Aranda, 2011; SEO/BirdLife, 2012). Thus, just one of the nearby larger and well preserved estuaries, the Santoña Marshes, host a wintering population of $>5500$ individuals (Navedo et al., 2007).

Most of the species had uncertain or stable population trends, with only five having positive population trends, and two negative trends. Part of this uncertainty is likely to be due to a high over-dispersion of the data, with few estuaries hosting relevant numbers for the majority of waterbirds. Interestingly, the five species with positive population trends also showed positive trends for both the entire Basque region and Spain (Table 3), but not in Europe, where they all were found to decrease (Tucker \& Heath, 2004). Accordingly, it can be suggested that the increasing amount of waterbirds that overwinter in the Basque 


\begin{tabular}{|c|c|c|c|c|c|c|}
\hline Species & IUCN & SPEC & $\begin{array}{c}\text { Trend } \\
\text { (this work) }\end{array}$ & $\begin{array}{l}\text { Trend } \\
\text { (Basque) }\end{array}$ & $\begin{array}{l}\text { Trend } \\
\text { (Spain) }\end{array}$ & $\begin{array}{l}\text { Trend } \\
\text { (Europe) }\end{array}$ \\
\hline Little grebe & LC & Non-SPEC & + & + & + & - \\
\hline Great crested grebe & LC & Non-SPEC & Uncertain & $=$ & + & Unknown \\
\hline Black-necked grebe & LC & Non-SPEC & Uncertain & + & + & Unknown \\
\hline Great cormorant & LC & Non-SPEC & $=$ & $=$ & + & + \\
\hline European shag & LC & Non-SPEC & + & + & 0 & - \\
\hline Grey heron & LC & Non-SPEC & $=$ & $=$ & + & Unknown \\
\hline Little egret & LC & Non-SPEC & $=$ & + & + & + \\
\hline Cattle egret & LC & Non-SPEC & Uncertain & ) & + & + \\
\hline Greylag goose & LC & Non-SPEC & Uncertain & + & + & + \\
\hline Eurasian wigeon & LC & Non-SPEC & Uncertain & - & - & - \\
\hline Gadwall & LC & SPEC 3 & Uncertain & + & + & Unknown \\
\hline Eurasian teal & LC & Non-SPEC & + & + & + & Unknown \\
\hline Mallard & LC & Non-SPEC & Uncertain & - & + & - \\
\hline Northern shoveler & LC & SPEC 3 & + & + & + & - \\
\hline Common moorhen & LC & Non-SPEC & Uncertain & () & () & Unknown \\
\hline Eurasian coot & LC & Non-SPEC & Uncertain & - & + & - \\
\hline Northern lapwing & LC & SPEC 2 & Uncertain & () & () & \\
\hline Eurasian oystercatcher & LC & Non-SPEC & Uncertain & () & + & - \\
\hline Grey plover & LC & Non-SPEC & - & - & + & - \\
\hline Common ringed plover & LC & Non-SPEC & Uncertain & & + & \\
\hline Eurasian curlew & NT & SPEC 2 & Uncertain & Uncertain & + & - \\
\hline Redshank & LC & SPEC 2 & Uncertain & () & + & Unknown \\
\hline Common greenshank & LC & Non-SPEC & Uncertain & + & + & $=$ \\
\hline Ruddy turnstone & LC & Non-SPEC & + & 0 & + & - \\
\hline Common sandpiper & LC & SPEC 3 & Uncertain & 0 & + & \\
\hline Purple sandpiper & LC & Non-SPEC & Uncertain & 0 & () & - \\
\hline Dunlin & LC & SPEC 3 & - & - & + & - \\
\hline Yellow-legged gull & LC & Non-SPEC & $=$ & $=$ & + & + \\
\hline Lesser black-backed gull & LC & Non-SPEC & Uncertain & + & + & + \\
\hline Black-headed gull & LC & Non-SPEC & $=$ & $=$ & + & - \\
\hline Mediterranean gull & LC & Non-SPEC & Uncertain & + & Unknown & $=$ \\
\hline Common guillemot & LC & Non-SPEC & Uncertain & ) & ) & + \\
\hline Razorbill & LC & Non-SPEC & Uncertain & 0 & ) & + \\
\hline
\end{tabular}

SPEC criteria: non-SPEC, favourable conservation status in Europe; 2-3, unfavourable conservation status in Europe. 
estuaries was not explained merely by increasing population trends at their breeding areas. The improvement in local conditions might have contributed to such results, at least in part. The creation/restoration of natural habitat at coastal marshes such as Urdaibai and Txingudi is likely to have promoted the occurrence of some waterbirds [e.g., little grebes Tachybaptus ruficollis (Pallas, 1764) or some ducks like the Eurasian teal Anas crecca L., 1758 and the northern shoveler Anas clypeata L., 1758] that were relatively rare at the beginning of the survey period (Arizaga et al., 2014). Specific research should be done in order to test this hypothesis. Moreover, we cannot reject the idea that the increasing trends of these birds in our study area might also be associated to the fact that some waterbirds might have shown a geographic re-distribution of their wintering areas.

Only two species showed negative trends, all shorebirds [grey plover Pluvialis squatarola (L., 1758), dunlin]. These two species are experiencing strong population declines also in the entire Basque region and in Europe, but, not in Spain, where they were found to increase moderately (Table 3). Particular conditions at regional levels might explain these variations within Spain (González \& Pérez-Aranda, 2011).

Finally, the species with stable population trends in our estuaries had stable (for the Basque area) or increasing (for Spain and Europe) population trends, indicating in this case a relatively uniform pattern.

In conclusion, the waterbird assemblage wintering on the Basque estuaries consists of a relatively poor community, dominated by gulls, especially the yellow-legged and the black-headed gulls. This assemblage, moreover, is also small in terms of abundance, and is of low importance from a peninsular standpoint (although, locally, it is important). The assemblage is subdivided into two clusters, dominated, respectively by the two most common gull species. Finally, most of the species had uncertain or stable population trends, with only five species showing positive population trends, and two having negative trends. The causes underlying such trends remain unidentified.

Table 3.- Conservation status (according to the IUCN -International Union for Conservation of Nature- and SPEC criteria) (Tucker \& Heath, 2004) and trends for 33 species (Table 2) of waterbirds wintering on the Basque estuaries (positive, + ; negative, $-;$ stable, $=$; uncertain/unknown). Trend sources: Basque estuaries, this work; Basque wetlands, Fernández-García et al. (2012); Spain, González \& PérezAranda (2011); Europe, Tucker \& Heath (2004). The symbol () refers to species non-studied in the reference literature.

Tabla 3. Estatus de conservación (según la lista de la UICN -Unión Internacional para la Conservación de la Naturaleza-y el criterio SPEC) (Tucker \& Heath, 2004) y tendencias para 33 especies (Tabla 2) de aves acuáticas invernantes en los estuarios vasco (positiva, + ; negativa, -; estable, $=$; incierta/desconocida. Fuentes: estuarios de la costa vasca, este artículo; humedales vascos, Fernández-García et al. (2012); España, González \& Pérez-Aranda (2011); Europa, Tucker \& Heath (2004). El símbolo () hace referencia a especies no estudiadas (tratadas) en la fuente correspondiente. 


\section{Acknowledgements}

The data used in this study were mostly collected by volunteers. Without their help studies like this are not possible. The data were compiled and published by IHOBE (Basque Government). Two reviewers provided very valuable comments that helped us to improve an earlier version of this work.

\section{Bibliography}

- Almaraz, P., Green, A.J., Aguilera, E., Rendón, M.A., Bustamante, J. 2012. Estimating partial observability and nonlinear climate effects on stochastic community dynamics of migratory waterfowl. J. Anim. Ecol. 81: 1113-1125.

- Amat, J.A., Ferrer, X. 1988. Respuesta de los patos invernantes en España a diferentes condiciones ambientales. Ardeola 35: 59-70.

- Anónimo. 1996. Evolución de la comunidad de aves acuáticas en la Reserva de la Biosfera de Urdaibai. S. O. Lanius. Inédito.

- Arizaga, J., Aldalur, A., Herrero, A., Cuadrado, J., Díez, E., Crespo, A. 2014. Foraging distances of a resident yellow-legged gull (Larus michahellis) population in relation to refuse management on a local scale. Eur. J. Wildl. Res. 60: 171-175.

- Arizaga, J., Cepeda, X., Maguregi, J., Unamuno, E., Ajuriagogeaskoa, A., Borregón, L., Azkona, A., Unamuno, J. M. 2014. The Influence of the Creation of a Lagoon on Waterbird Diversity in Urdaibai, Spain. Waterbirds 37: 111-118.

- Arizaga, J., Galarza, A., Herrero, A., Hidalgo, J., Aldalur, A. 2009. Distribución y tamaño de la población de la Gaviota Patiamarilla Larus michahellis lusitanius en el País Vasco: tres décadas de estudio. Rev. Catalana d'Ornitologia 25: 32-42.

- Avilés, J. M., Parejo, D. 1999. Aves limícolas (Charadrii) en un embalse del centro de la península ibérica durante un ciclo anual: zonas interiores vs. zonas litorales. Miscellània Zool. 22: 1-10.

- Beazley, M. 1993. Wetlands in danger. IUCN. London.

- Boere, G., Galbraith, C., Stroud, D. 2006. Waterbirds around the world. The Stationery Office. Edinburgh.

- Domínguez, J. 1997. Invernada y migración de limícolas en el litoral atlántico ibérico. En: Las aves limícolas en España. A. Barbosa: 35-75. Organismo Autónomo de Parques Nacionales. Madrid.

- Fernández-García, J.M., Gracianteparaluceta, A., Planillo, A. 2012. Abundancia, distribución y tendencia de las poblaciones de aves acuáticas invernantes en la Comunidad Autónoma del País Vasco. Departamento de Medio Ambiente y Política Territorial (Gobierno Vasco). Inédito. 
- Galarza, A., Domínguez, A. 1989. Urdaibai: Avifauna de la ría de Guernica. Diputación Foral de Bizkaia. Bilbao.

- Galarza, A., Herrero, A., Domínguez, J.M., Aldalur, A., Arizaga, J. 2012. Movements of Mediterranean Yellow-legged Gulls Larus michahellis to the Bay of Biscay. Ringing Migr. 27: 26-31.

- Galarza, A., Tellería, J.L. 2003. Linking processes: effects of migratory routes on the distribution of abundance of wintering passerines. An. Biodivers. Conserv. 26: 19-27.

- Garaita, R. 2012. Migración postnupcial de la espátula en Urdaibai. Informe 2012. Patronato de la Reserva de la Biosfera de Urdaibai. Inédito.

- González, R., Pérez-Aranda, D. 2011. Las aves acuáticas en España, 1980-2009. SEO/BirdLife. Madrid.

- Granadeiro, J.P., Andrade, J., Palmeirim, J.M. 2004. Modelling the distribution of shorebirds in estuarine areas using generalized additive models. J. Sea Res. 52: 227-240.

- Hammer, Ø., Harper, D.A.T. , Ryan, P.D. 2001. PAST: Palaeontological Statistics software package for education and data analysis. Palaentologia Electronica 4(1) art. 4. Disponible en: http://palaeo-electronica.org/2001_1/past/issue1_01.htm.

- Ihobe. 2012. Estimas de aves acuáticas invernantes en la Comunidad Autónoma del País Vasco: Temporada 2012. Gobierno Vasco. Bilbao.

- Keddy, P. A. 2010. Wetlands Ecology. Cambridge university Press. Cambridge.

- Krebs, J.R., Davis, N.B. 1993. An introduction to behavioural ecology. Blackwell. Oxford.

- Madroño, A., González, C., Atienza, J.C. 2004. Libro Rojo de las Aves de España. DGB-SEO/ BirdLife. Madrid.

- Navedo, J.G., Masero, J.A., Juanes, J.A. 2007. Updating waterbird population estimates within the East Atlantic flyway: status and trends of migratory waterbirds in Santoña marshes. Ardeola 54: 237-249.

- Obeso, J. R. 1988. La invernada de gaviotas en las costas del norte de España. Ardeola 35: 247256.

- Pannekoek, J., Van Strien, A. 2005. TRIM 3 Manual. (Trends and Indices for Monitoring data). Research paper no. 0102. Statistics Netherlands. Voorburg.

- Rendón, M.A., Green, A.J., Aguilera, E., Almaraz, P. 2008. Status, distribution and long-term changes in the waterbird community wintering in Doñana, south-west Spain. Biol. Conserv. 141: 1371-1388.

- Rose, P.M. , Scott, D.A. 1997. Waterfowl Population Estimates. Wetlands Internation Publication, No. 44. Wageningen.

-Santos, C.D., Granadeiro, J.P., Palmeirim, J.M. 2005. Feeding ecology of Dunlin Calidris alpina in a southern European estuary. Ardeola 52: 235-252. 
- SEO/BirdLife. 2012. Atlas de las aves en invierno en España 2007-2010. Ministerio de Agricultura, Alimentación y Medio Ambiente-SEO/BirdLife. Madrid. Smit, C.J., Piersma, T. 1989. Numbers, midwinter distribution, and migration of waders populations using the East Atlantic flyway. En: Flyways and reserve networks for waterbirds. H. Boyd, J.H. Pirot (Ed.): 24-63. IWRP Special Publication 9.

- Tellería, J. L. 1988. Invernada de aves en la Península Ibérica. SEO/BirdLife. Madrid.

- Tellería, J. L., Ramírez, A., Galarza, A., Carbonell, R., Pérez-Tris, J., Santos, T. 2009. Do migratory pathways affect the regional abundance of wintering birds? A test in northern Spain. J. Biogeogr. 36: 220-229.

- Tucker, G.M., Heath, M.F. 2004. Birds in Europe: population estimates, trends and conservation status. BirdLife International. Cambridge.

-Weller, M. W. 1999. Wetland Birds. Cambridge University Press. Cambridge.

-Wetlands International. 2012. Waterbird Population Estimates, 5th Ed. Wetlands International. Wageningen, The Netherlands.

- Zwarts, L., Bijlsma, R.G., Van der Kamp, J., Wymenga, E. 2009. Living on the edge: Wetlands and birds in a changing Sahel. KNNV Publishing. Zeist.

- Date of reception: 17-12-2014

- Date of acceptance: 28-05-2015

Associate Editor: Iván de la Hera 
Appendix I

Abundance (counts) of waterbird species wintering at the Basque estuaries. Note that not all species were counted at Urdaibai (see Methods for details). This information can be downloaded via this link:

http://www.aranzadi.eus/fileadmin/docs/Munibe/Datos_suplementarios_2014_011_Appendix1.xIsx

Appendix II

Winter abundance of waterbirds. Note that not all species were counted at Urdaibai (see Methods for details). The symbol (-) indicates that the site was not surveyed that particular year. Site code as in Table 1. This information can be downloaded via this link:

http://www.aranzadi.eus/fileadmin/docs/Munibe/Datos_suplementarios_2014_011_Appendix2.xlsx

Apéndice I

Abundancia (número de ejemplares) de aves acuáticas invernantes en estuarios de la costa vasca. Nótese que todas las especies no fueron censadas en Urdaibai (para más detalles ver Métodos). Esta información puede descargarse a través de este enlace:

http://www.aranzadi.eus/fileadmin/docs/Munibe/Datos_suplementarios_2014_011_Appen$\operatorname{dix} 1 . x \mid s x$

Apéndice II

Abundancia invernal de aves acuáticas. Nótese que todas las especies no fueron censadas en Urdaibai (para más detalles ver Métodos). El símbolo (-) indica que ese estuario no se censó en ese año en particular. Código de estuario como en la Tabla 1. Esta información puede descargarse a través de este enlace:

http://www.aranzadi.eus/fileadmin/docs/Munibe/Datos_suplementarios_2014_011_Appen$\operatorname{dix} 2 . x \mid s x$ 